\title{
PENGARUH RELIGIUSITAS DAN KEPRIBADIAN LIMA FAKTOR TERHADAP PRASANGKA SOSIAL KEPADA JAMA'AH TABLIGH
}

\author{
Syamsul Bachri \\ Ikhwan Lutfi \\ Gazi Saloom \\ UIN Syarif Hidayatullah Jakarta \\ ikhwan.lutfi@uinjkt.ac.id
}

\begin{abstract}
The life of heterogen community tends to relate to social problems. One of those such social problem is social prejudice that can create more complex problem in social life. In this matter, religion can be source of social prejudice as what happened to the Group of Jamaah Tabligh. This research aimed to know some psychological factors that influence prejudice toward Jamaah Tabligh Group. This research used quantitative method with multiple regression as technique of analysis and lay people of Jakarta as respondents. The samples were chosen by non probability sampling technique. The research concluded that religiousity and big five personality have significant impact toward prejudice.
\end{abstract}

Keywords: Religiosity, personality, prejudice

\begin{abstract}
Abstrak
Kehidupan komunitas heterogen cenderung berhubungan dengan masalah social. Salah satu dari masalah sosial itu adalah prasangka sosial yang dapat menimbulkan masalah yang lebih kompleksdi kehidupan sosial. Dalam masalah ini, agama dapat menjadi sumber prasangka sosial seperti yang terjadi pada kelompok Jamaah Tabligh. Penelitian ini menggunakan metode kuantitatif dengan regresi berganda sebagai teknik analisis dan menggunakan masyarakat Jakarta sebagai responden. Non probability sampling digunakan sebagai teknik sampling. Penelitian ini menyimpulkan bahwa religiusitas dan big five personality memiliki pengaruh signifikan terhadap prasangka.
\end{abstract}

Kata kunci: Religiusitas, kepribadian, prasangka

Diterima: 16 Mei 2013 Direvisi: 24 Juni $2013 \quad$ Disetujui: 2 Juli 2013 


\section{PENDAHULUAN}

Prasangka sosial adalah permasalahan yang sering terjadi pada belahan dunia mana pun. Indonesia pernah mengalami permasalahan yang berkaitan dengan prasangka sosial, terutama prasangka terhadap etnis. Menurut Mar'at, (dalam Irmawati, 2004) permasalahan yang berkaitan dengan prasangka sosial, terutama prasangka terhadap etnis. Menurut Mar'at, (dalam Irmawati, 2004) permasalahan yang berkaitan dengan prasangka sosial di Indonesia sering ditujukan pada golongan non-pribumi yakni kelompok etnis keturunan Cina. Bersumber dari Sarlito (2006), peneliti mendapatkan bahwa prasangka sosial adalah akar dari segala macam permasalahan yang sering terjadi, sebagai contoh orang yang dicurigai maling bisa dibakar hidup hidup padahal belum tentu ia benarbenar maling.

Prasangka sosial akan lebih terasa apabila dikaitkan dengan kelompok sosial, sehingga individu yang menjadi anggota kelompok tersebut menjadi patut untuk diprasangkai. Kelompok sosial dan juga berkaitan dengan agama salah satunya adalah jama'ah tabligh. Salah satu aktivitas dari jama'ah tabligh adalah program khuruj yaitu i'tikaf dan berda'wah atau syi'ar islam selama 3 hari, 40 hari atau 4 bulan Ketika anggota dari jama'ah tabligh sedang melakukan program khuruj tersebut bermacam perlakuan sering diterima oleh Jama'ah tabligh. Salah satu kasus yang muncul prasangka sosial di masyarakat tentang jama'ah tabligh yaitu seperti peneliti kutip dari Antaranews.com (2009), bahwa terjadi penangkapan sembilan orang dari jamaah tabligh yang sedang khuruj di salah satu masjid di Banyumas dan delapan orang di Surakarta, dan peristiwa tersebut terjadi karena ada kecurigaan dari masyarakat.

Fenomena prasangka sosial dapat terjadi pada setia dan tanpa disadarinya. Hal ini menunjukkan bahwa proses prasangka sosial dapat secara otomatis dan dipengaruhi lingkungan sosial yang mendukung proses terjadinya prasangka sosial. Salah satu variabel yang berhubungan dengan prasangka sosial adalah religiusitas, Duck \& Hunsberger (1999), Herek (1987) dan Layte dkk. (2001) menyebutkan bahwa, orientasi religius intrinsik berkorelasi negatif dengan prasangka rasial. Tetapi religius intrinsik berkorelasi secara positif dengan prasangka homoseksual (dalam Rowat, LaBouff, Johnson, Froese dan Tsang, 2009). 
Selain keberagamaan, kepribadian merupakan hal yang sangat terkait dengan prasangka sosial. Dari sudut pandang kepribadian dapat dikatakan 
bahwa prasangka sosial disebabkan oleh kepribadian manusia atau berhubungan dengan karakteristik kepribadian seseorang Adorno, renkelBrunswik, Levinson, \& Sanford, 1950; Altenmeyer 1981; Ekehammar \& Akrami, 2003 dalam Ekehammar \& Akrami, 2007). Menurut Allport (dalam Duckitt, 2005) struktur karakter atau kepribadian individu adalah penentu dasar prasangka.

Brown (2010) berpendapat bahwa prasangka adalah sikap, perasaan atau perilaku terhadap anggota sebuah kelompok dimana semua kompenen tersebut secara langsung atau tidak lapngsung berpengaruh secara negatif atau bahkan anti pati terhadap kelompok tersebut. Unsur-unsur Prasangka Sosial: 1. Komponen kognitif. Berisi persepsi, belief, dan harapan individu terhadap berbagai kelompok sosial Belief dan harapan yang ditujukan pada anggota dan kelompok tertentu dapat beragam sejalan dengan dimensi yang dimilikinya (Brown, 2010).

2. Komponen Afektif. Pada dasarnya merujuk pada perasaan atau reaksi emosi terhadap objek Salah satu contoh sikap tersebut adalah mencintai/menyukai/tertarik, dan sebaliknya benci/tidak suka/jijik. Termasuk didalamnya friendliness dan unfriendliness terhadap obyek prasangka.

3. Komponen Perilaku (Konasi). Merupakan komponen yang berhubungan dengan kecenderungan bertindak terhadap objek sikap, baik positif maupun negatif. Komponen ini akan menentukan sebenarnya diskrepansi antara komponen kognitif dan afektif.

Pengukuran prasangka sosial telah banyak dilakukan oleh para peneiliti di dunia. Salah satunya adalah Ekehammar dan Akrami (2007) yang menggunakan skala Likert yang terdui dari 5 pilihan, mulai dari sangat tidak setuju sampai dengan sangat setuju (5) dan skoring terscbut dibalik untuk item unfavorable. Alat ukur tersebut bernama modern racial prejudice scale digunakan untuk mengukur prasangka terhadap pada orangorang Skandinavia Item berdasarkan modern racism sacle dari McConahay (1986).

Allport dan Ross (1976) melaporkan bahwa mereka yang secara instrinsik dan ekstrinsik beragama adalah orang yang paling berprasangka dibandingkan orang lain selain itu, Allport dan Ross memprediksikan bahwa general religiousness akan berkorelasi secara positif dengan semua prasangka (dalam Rowatt dkk, 2009). Hubungan antara prasangka dan trait 
kepribadian bukan hal yang baru dalam psikologi sosial (Dollard et. al., 1939 dalam Heaven, 2001), dimensi kepribadian RWA menjadi salah satu prediktor terkuat terhadap prasangka di level multinasional (Sibley \& Duckitt, 2008, dalam Rowatt dkk. 2009).

Menurut Fetzer (1999) definisi religiusitas adalah seberapa kuat individu penganut agama merasakan pengalaman beragama sehari-hari (daily spiritual experience), mengalami kebermaknaan hidup dengan beragama (religion meaning), mengekspresikan keagamaan sebagai sebuah nilai (value), meyakini ajatan agamanya (belief) memaafkan (forgiveness), melakukan praktek beragama (ibadah) secara menyendiri (private religious practice), menggunakan agama sebagai coping (religious/spiritual coping), mendapat dukungan sesama agama (religious support), mengalami sejarah keagamaan (religious/spiritual history), komitmen (commitment), mengikuti organisasi kegiatan keagamaan (organizational religiousness) dan meyakini pilihan agamanya (religious preference). Jadi, dapat dikatakan bahwa religiusitas seseorang dapat dilihat dari seberapa kuat penghayatan dan pemahaman terhadap agama melalui dimensi-dimensi religiusitas yang telah disebutkan. Religiusitas memiliki 12 aspek. Aspek-aspek tersebut meliputi:

1. Daily spiritual experience. Merupakan persepsi individu terhadap sesuatu yang berkaitan dengan transenden dalam kehidupan sehari-hari dan persepsi terhadap interaksinya pada kehidupan tersebut, sehingga lebih kepada pengalaman (Underwood, dalam Fetzer Institute, 1999).

2. Meaning. Sejauh mana agama dapat menjadi tujuan hidupnya (Pargament dalam Fetzer Institute, 1999).

3. Value. Pengaruh keimanan terhadap nilai-nilai hidup, seperti mengajarkan tentang nilai cinta, saling menolong, saling melindungi dan sebagainya (Idler, dalam Fetzer Institute, 1999).

4. Belief. Merupakan sentral dari religiusitas. Religiusitas merupakan keyakinan akan konsep-konsep yang dibawa oleh suatu agama (Idler, dalam Fetzer Institute, 1999).

5. Forgiveness. Mencakup 5 dimensi turunan, yaitu pengakuan dosa, merasa diampuni oleh Tuhan, merasa dimaafkan oleh orang lain memaafkan orang lain dan memaafkan diri sendiri (dler, dalam Fetzer Institute, 1999). 
6. Private religious practice. Merupakan perilaku beragama dalam praktek agama meliputi ibadah, mempelajari kitab (Levin, dalam Fetzer Institute, 1999). 
7. Religious spiritual coping Merupakan coping stress dengan menggunakan pola dan metode religius. Seperti dengan berdoa, beribadah untuk menghilangkan stress, dan sebagainya (Pargament, dalam Fetzer Institute, 1999).

8. Religious support Aspek hubungan sosial antara individual dengan pemeluk agama sesamanya (Krause, dalam Fetzer Institute, 1999).

9. Religious. spiritual history Terdapat empat aspek yang dapat diukur berkaitan dengan sejarah keberagamaan atau spiritualitas seseorang, yaitu biografi keagamaan, pertanyaan-pertanyaan mengenai sejarah keagamaan/spiritual, pengalaman keagamaan/spiritual yang mengubah hidup, dan kematangan spiritual, (George, dalam Fetzer Institute, 1999).

10. Commitment. Seberapa jauh individu mementingkan agamanya, komitmen, serta berkontribusi kepada agamanya Williams (dalam Fetzer Institute, 1999).

11. Organizational religiousness. Konsep ang mengukur seberapa jauh individu ikut serta dalam lembaga keagamaan yang ada di masyarakat dan beraktifitas di dalamnya (dler, dalam Fetzer Institute, 1999).

12. Religious preference. Memandang sejauh mana individu membuat pilihan dan memastikan pilihan agamanya (Ellison, dalam Fetzer Institute, 1999).

Kepribadian big five adalah pendekatan yang digunakan dalam psikologi untuk melihat kepribadian manusia melalui trait yang tersusun dalam lima buah dimensi kepribadian yang telah dibentuk dengan menggunakan analisis faktor. Lima dimensi trait kepribadian tersebut adalah neuriticism, Extraversion, agreeableness, openness dan Conscientiousness (Friedman \& Schustack, 2008). Dimensi-dimensi dari kepribadian Big five Costa dan McCrae (2003) (dalam Zhao \& Seibert, 2006) sebagai berikut:

Openness to experience $(\mathbf{O})$. Sebuah dimensi kepribadian yang cenderung mencirikan secara intelektual penasaran dan cenderung mencari pengalaman baru dan mengeksplorasi ide-ide baru. Seseorang openness to experience yang tinggi dapat digambarkan sebagai orang yang kreatif, inovatif, imajinatif, reflektif, dan tidak tradisional. Seseorang dengan openness to experience yang rendah dapat dicirikan sebagai orang yang konvensional, ketertarikannya sempit, dan tidak analitis. 
Conscientiousness (C). biasanya digambarkan sebagai orang yang well organize, tepat waktu dan ambisius (Feist \& feist, 2009), berfikir sebelum 
bertindak, mengikuti peraturan dan norma, terencana, terorganisir dan memprioritaskan tugas.

Extraversion (E). menggambarkan sejauh mana seseorang itu asertif, dominan, enerjik, aktif, aktif berbicara, dan antusias (Costa \& McCrae, 1992). Orang yang memiliki skor Extraversion tinggi cenderung ceria, menyukai orang-orang dan kelompok besar. Extraversion yang rendah lebih suka menghabiskan lebih banyak waktu sendirian dan dikategorikan sebagai orang yang tidak ramah, pendiam, dan mandiri.

Agreeableness (A). Mengukur orientasi interpersonal seseorang. Seseorang yang agreeableness tinggi dapat dicirikan sebagai orang yang penuh kepercayaan, pemaaf, peduli, altruistik, dan mudah tertipu. Seseorang yang memiliki agreeableness paling rendah dapat dicirikan sebagai orang yang manipulative, berpusat pada diri sendiri, mudah curiga, dan kejam (Costa \& McCrae, 1992; Digman, 1990).

Neuroticism (N). Mewakili perbedaan individu dalam penyesuaian dan stabilitas emosional. Seseorang yang neurotisismenya tinggi cenderung mengalami sejumlah emosi negatif termasuk kecemasan, kebencian, depresi, kesadaran diri, impulsivitas, dan kerentanan (Costa \& McCrae, 1992). Orang yang skornya rendah pada neurotisisme dapat dikategorikan sebagai percaya diri, tenang, tidak mudah tersinggung, dan relax.

\section{METODE}

\section{Populasi dan Sampel}

Penyebaran data secara manual populasi dari penelitian ini adalah masyarakat wilayah Bintaro, Rempoa, dan Ciputat dengan kisaran usia antara 16-55 tahun.

Sampel dalam penelitian ini berjumlah 159 sampel dengan pembagian berdasarkan jenis kelamin yaitu 90 orang laki-laki dan 69 orang perempuan. Dalam penelitian ini pengambilan sampel dilakukan secara accidental sampling, dimana sampel yang diambil adalah masyarakat umum yang terbatas pada golongan atau kelompok tertentu. Teknik ini tergolong dalam non probability sampling yang berarti tidak semua anggota populasi memiliki kesempatan yang sama untuk menjadi subjek penelitian.

\section{Skala Religiusitas}


Pengukuran yang akan peneliti gunakan untuk mengukur religiusitas adalah adaptasi skala religiusitas Multidimensional Measurement of Religiusness/ 
Spirituality) dari Fetzer Institute (1999) yang berdasarkan buku Multidimensional Measurement of Religiusness/Spirituality for Use in Health Research: A Report of the Fetzer Institute/ National Institute on Aging Working Group. Dalam skala ini terdapat dua belas sub skala pengukuran yang bertujuan untuk mengukur dimensi Daily Spiritual Experiences. Meaning, Values, Beliefs, Forgiveness, Private Religious Practices, Religious/Spiritual Coping, Religious Support, Religious Spiritual History, Commitment, Organizational Religiousness, dan Religious Preference.

\section{Skala Kepribadian Big Five}

Untuk mengukur trait big five individu alat ukur yang digunakan dalam penelitian ini adalah International Personality Item Pool NEO (IPIP- NEO) yang dibuat oleh Lewis Goldberg pada tahun 1992. Skala ini dibuat berdasarkan teori Big Five yang digunakan oleh Costa dan McCrae dalam membuat NEO PI-R pada tahun 1992, alat ukur ini berjumlah 240 item. Skala IPIP-NEO berjumlah 100 item, setiap trait berjumlah 20 item. Skala ini diadaptasi dan diterjemahkan oleh Adriaan H. Boon Van Ostade bernama 100 Big Five factor markies. Peneliti menggunakan skala likert yang mengacu pada IPIP-NEO tersebut dan dalam penelitian ini peneliti hanya mengambil beberapa item dari tiap dimensi sehingga berjumlah 37 iterm.

\section{Skala Prasangka Sosial}

Skala ini disusun menggunakan model skala likert yang terdiri dari pernyataan yang disusun dalam bentuk pernyataan favourable dan unfavourable yang disusun berdasarkan dari tiga indikator yaitu, kognitif, afektif dan konatif. Banyaknya pernyataan berjumlah 28 item pernyataan favourable, sedangkan yang unfavourable sebanyak 10 pernyataan.

Dalam penelitian ini validitas konstruk dari setiap instrument diuji dengan analisis faktor konfirmatori (Confirmatory Factor Analysis CFA).Adapun yang dimaksud dengan CFA adalah teknik analisis statistik yang digunakan untuk menguji validitas konstruk dari tiap item. Peneliti menggunakan Confirmatory Factor Analysis (CFA) dengan software Lisrel 8.30 (Joreskog dan Sorbom, 1994). 


\section{HASIL}

Pada tahapan ini peneliti menguji hipotesis penelitian dengan teknik analisis regresi multivariat, yang perhitungannya menggunakan SPSS 17.0. Adapun hasil uji $\mathrm{F}$ dilihat pada tabel berikut:

\section{Tabel 1}

ANOVA ${ }^{b}$

\begin{tabular}{|c|c|c|c|c|c|c|}
\hline Model & & Sum of Squares & Df & Mean Square & $\mathbf{F}$ & Sig. \\
\hline \multirow[t]{3}{*}{1} & Regression & 51.344 & 19 & 2.439 & 3.653 & $0.000^{\mathrm{a}}$ \\
\hline & Residual & 71.601 & 111 & 0.668 & & \\
\hline & Total & 122.944 & 129 & & & \\
\hline
\end{tabular}

a. Predictors: (Constant), Conscientiousness, preference, forgiveness, values, beliefs, neuroticism, support, daily, Extraversion, organizational, openness, meaning, commitment, agreebleness, practice, history, coping, usia

b. Dependent Variable: prasangka

Pada tabel diatas kolom keenam, signifikansi sebesar $0,000(\mathrm{p}<0,05)$ dan hipotesis nihil atau $\left(\mathrm{H}_{0}\right)$ ditolak. Hal ini berarti ada pengaruh yang signifikan seluruh independen variabel terhadap prasangka sosial. Untuk tabel $\mathrm{R}$ square, dapat dilihat sebagai berikut:

\section{Tabel 2}

$R$ Square

\begin{tabular}{ccccc}
\hline Model & R & R Square & Adjusted R Square & Standard Error of the Estimate \\
\hline 1 & $0.646^{\mathrm{a}}$ & 0.419 & 0.324 & 0.79955634 \\
\hline
\end{tabular}

a. Predictors: (Constant), Conscientiousness, preference, forgiveness, values, beliefs, neuroticism, support, daily, Extraversion, organizational, openness, meaning, commitment, agreebleness, practice, history, coping, usia

b. Dependent Variable: prasangka

Kemudian langkah berikutnya melihat koefisien regresi dari setiap independen variabel. Jika nilai $\mathrm{t}>1,96$ dan nilai signifikansi $(\mathrm{P}<0,05)$, maka koefisien regresi tersebut signifikan yang berarti bahwa IV tersebut memiliki dampak yang signifikan terhadap prasangka sosial. Berikut tabel koefisien regresi dari setiap independen variabel: 
Tabel 3

\begin{tabular}{|c|c|c|c|c|c|c|}
\hline \multirow{2}{*}{ Model } & & \multicolumn{2}{|c|}{$\begin{array}{c}\text { Unstandardized } \\
\text { Coefficients } \\
\end{array}$} & $\begin{array}{l}\text { Standardized } \\
\text { Coefficients }\end{array}$ & \multirow[b]{2}{*}{$\mathbf{T}$} & \multirow[b]{2}{*}{ Sig. } \\
\hline & & B & Std. & Beta & & \\
\hline \multirow[t]{20}{*}{1} & (Constant) & -0.022 & 0.071 & & $0 . \overline{3} 02$ & 0.763 \\
\hline & Daily & 0.047 & 0.107 & 0.042 & 0.437 & 0.663 \\
\hline & Meaning & -0.028 & 0.119 & -0.024 & $0 . \overline{2} 34$ & 0.815 \\
\hline & Values & 0.000 & 0.082 & 0.000 & 0.005 & 0.996 \\
\hline & Beliefs & -0.050 & 0.100 & -0.043 & $0 . \overline{495}$ & 0.622 \\
\hline & Forgiveness & -0.127 & 0.093 & -0.111 & $1 . \overline{358}$ & 0.177 \\
\hline & Practice & 0.033 & 0.119 & 0.030 & 0.274 & 0.785 \\
\hline & Coping & -0.682 & 0.161 & -0.482 & $4 . \overline{249}$ & 0.000 \\
\hline & Support & -0.451 & 0.155 & -0.276 & $2 . \overline{9} 13$ & 0.004 \\
\hline & History & 0.273 & 0.136 & 0.224 & 2.005 & 0.047 \\
\hline & Commitment & -0.094 & 0.134 & -0.072 & $\begin{array}{c}- \\
0.698\end{array}$ & 0.486 \\
\hline & Organizational & -0.186 & 0.096 & -0.174 & 1.933 & 0.056 \\
\hline & Preference & -0.002 & 0.123 & -0.001 & $\begin{array}{c}- \\
0.014\end{array}$ & 0.989 \\
\hline & Neuroticism & -0.073 & 0.090 & -0.068 & $\begin{array}{c}- \\
0.810\end{array}$ & 0.420 \\
\hline & Extraversion & -0.214 & 0.101 & -0.195 & $2 . \overline{106}$ & 0.037 \\
\hline & Agreebleness & -0.033 & 0.118 & -0.030 & $0 . \overline{-}$ & 0.780 \\
\hline & Openness & -0.021 & 0.104 & -0.020 & $0 . \overline{201}$ & 0.841 \\
\hline & Conscientiousness & 0.235 & 0.107 & 0.222 & 2.204 & 0.030 \\
\hline & Usia & -0.003 & 0.008 & -0.033 & $0 . \overline{383}$ & 0.703 \\
\hline & Jenis Kelamin & -0.020 & 0.168 & -0.010 & $0 . \overline{116}$ & 0.908 \\
\hline
\end{tabular}

a. Dependent Variable: Prasangka 


\section{Pengujian Proporsi Varians masing-masing Independen Variabel}

Pengujian pada tahap ini bertujuan untuk melihat sejauh mana IV memberikan sumbangan terhadap DV.

\section{Tabel 4}

Proporsi Varians Prasangka Sosial

\begin{tabular}{lcccc}
\cline { 3 - 5 } \multicolumn{1}{c}{ IV } & $\mathbf{R}^{2}$ & $\mathbf{R}^{2}$ Change & F Hitung & DF \\
\hline Daily & 0.049 & 0.049 & 6.189 & 1.131 \\
Meaning & 0.121 & 0.072 & 10.629 & 1.130 \\
Values & 0.122 & 0.001 & 0.095 & 1.129 \\
Beliefs & 0.143 & 0.021 & 3.187 & 1.128 \\
Forgiveness & 0.190 & 0.047 & 7.330 & 1.127 \\
Practice & 0.196 & 0.006 & 0,890 & 1.126 \\
Coping & 0.265 & 0.070 & 11.857 & 1.125 \\
Support & 0.313 & 0.048 & 8.675 & 1.124 \\
History & 0.338 & 0.024 & 4.469 & 1.123 \\
Commitment & 0.354 & 0.007 & 1.222 & 1.119 \\
Organizational & 0.371 & 0.017 & 3.133 & 1.118 \\
Preference & 0.371 & 0.000 & 0.026 & 1.117 \\
Neuroticism & 0.376 & 0.005 & 0.857 & 1.116 \\
Extraversion & 0.391 & 0.015 & 2.870 & 1.115 \\
Agreebleness & 0.391 & 0.000 & 0.019 & 1.114 \\
Openness & 0.392 & 0.001 & 0.236 & 1.113 \\
Conscientiousness & 0.418 & 0.025 & 4.857 & 1.112 \\
Usia & 0.419 & 0.001 & 0.147 & 1.111 \\
Jenis Kelamin & 0.419 & 0.000 & 0.014 & 1.111 \\
\hline
\end{tabular}

Penjelasan dari tabel di atas akan dijabarka sebagai berikut:

- Variabel Daily memberikan sumbangan sebesar 4,9\% pada prasangka sosial. Artinya bervariasinya prasangka sosial pada jama'ah tabligh dipengaruhi oleh Daily sebesar 4,9\%.

- Variabel Meaning memberikan sumbangan sebesar 7,2\% pada prasangka sosial Artinya bervariasinya prasangka sosial pada jama'ah tabligh dipengaruhi oleh Meaning sebesar 7,2\%.

- Variabel Values memberikan sumbangan sebesar 0,1\% pada prasangka sosial Artinya bervariasinya prasangka sosial pada jama'ah tabligh dipengaruhi oleh Values sebesar $0,1 \%$.

- Variabel Beliefs memberikan sumbangan sebesar 2,1\% pada prasangka sosial. Artinya bervariasinya prasangka sosial pada jama'ah tabligh dipengaruhi oleh Beliefs sebesar 2,1\%. 
- Variabel Forgiveness memberikan sumbangan sebesar $4,7 \%$ pada prasangka sosial. Artinya bervariasinya prasangka sosial pada Jama'ah tabligh dipengaruhi oleh Forgiveness sebesar 4.7\%.

- Variabel Practice memberikan sumbangan sebesar 0,6\% pada prasangka sosial. Artinya bervariasinya prasangka sosial pada jama'ah tabligh dipengaruhi oleh Practice sebesar 0,6\%.

- Variabel Coping memberikan sumbangan sebesar 7,0\% pada prasangka sosial. Artinya bervariasinya prasangka sosial pada jama'ah tabligh dipengaruhi oleh Coping sebesar 7,0\%.

- Variabel Support memberikan sumbangan sebesar 4,8\% pada prasangka sosial. Artinya bervariasinya prasangka sosial pada jama'ah tabligh dipengaruhi oleh Support sebesar 48\%.

- Variabel History memberikan sumbangan sebesar 2,4\% pada prasangka sosial. Artinya bervariasinya prasangka sosial pada jama'ah tabligh dipengaruhi oleh History sebesar 2,4\%

- Variabel Commitment memberikan sumbangan sebesar $0,7 \%$ pada prasangka sosial. Artinya bervariasinya prasangka sosial pada jama'ah tabligh dipengaruhi oleh Commitment sebesar 0,7\%.

- Variabel Organizational memberikan sumbangan sebesar $1,7 \%$ pada prasangka sosial. Artinya bervariasinya prasangka sosial pada jama'ah tabligh dipengaruhi oleh Organizational sebesar 1,7\%.

- Variabel Preference memberikan sumbangan sebesar 0\% pada prasangka sosial. Artinya bervariasinya prasangka sosial pada jama'ah tabligh dipengaruhi oleh Preference sebesar 0\%.

- Variabel Neuroticism memberikan sumbangan sebesar 0,5\% pada prasangka sosial. Artinya bervariasinya prasangka sosial pada jama'ah tabligh dipengaruhi oleh Neuroticism sebesar 0,5\%.

- Variabel Extraversion memberikan sumbangan sebesar $1,5 \%$ pada prasangka sosial. Artinya bervariasinya prasangka sosial pada Jama'ah tabligh dipengaruhi oleh Extraversion sebesar 1,5\%.

- Variabel Agreebleness memberikan sumbangan sebesar 0\% pada prasangka sosial. Artinya bervariasinya prasangka sosial pada jama'ah tabligh dipengaruhi oleh Agreebleness sebesar 0\%.

- Variabel Openness memberikan sumbangan sebesar 0,1\% pada prasangka sosial. Artinya bervariasinya prasangka sosial pada jama'ah tabligh dipengaruhi oleh Openness sebesar $0,1 \%$. 
- Variabel Conscientiousness memberikan sumbangan sebesar 2,5\% pada prasangka sosial. Artinya bervariasinya prasangka sosial pada jama'ah tabligh dipengaruhi oleh Conscientiousness sebesar 2,5\%.

- Variabel usia memberikan sumbangan sebesar $0,1 \%$ pada prasangka sosial. Artinya bervariasinya prasangka sosial pada jama'ah tabligh dipengaruhi oleh Usia sebesar $0,1 \%$.

- Variabel jenis kelamin memberikan sumbangan sebesar 0\% pada prasangka sosial. Artinya bervariasinya prasangka sosial pada jama'ah tabligh dipengaruhi oleh Jenis kelamin sebesar $0 \%$.

\section{DISKUSI}

Dari variabel religiusitas ada pengaruh yang signifikan terhadap prasangka sosial pada jama'ah tabligh, yaitu dimensi Religious spiritual coping $(0,000)$, Religious Support $(0,004)$, dan Religious/Spiritual History $(0,047)$. Sedangkan variabel kepribadian big five yang berpengaruh terhadap prasangka sosial pada jama'ah tabligh adalah trait Extraversion $(0,037)$, dan Conscientiousness $(0,030)$. Proporsi varians secara seluruh IV terhadap DV adalah sebesar $41,8 \%$ atau $0,418 \%$. Artinya bervariasinya DV dipengaruhi oleh IV sebesar $41,8 \%$, dan $58,9 \%$ lainnya dipengaruhi oleh varibcl di luar penelitian ini.

Hasil utama dalam penelitian ini yaitu didapatkan bahwa hipotesis penelitian $(\mathrm{Ha})$ diterima dikarenakan terdapat pengaruh yang signifikan religiusitas dan trait kepribadian terhadap prasangka sosial. Sesuai dengan teori yang dikemukakan oleh Allport (1954/1979, dalam Batson dan Stocks, 2005), agama bisa menyebabkan prasangka dan bisa menghilangkan prasangka.

Perbedaan penelitian ini dengan penelitian yang telah dilakukan oleh Mavor dkk (2009) dan Rowatt dkk (2009) adalah dalam penelitian ini pengukuran religiusitas dilakukan dengan cara memisahkan dimensi- dimensi yang ada dalam variabel religiusitas yang dikemukakan dari Fetzer Institute (1999).

Begitu juga dengan kepribadian, dalam penelitian ini kepribadian mempunyai pengaruh yang signifikan terhadap prasangka sosial pada jama'ah tabligh. Sesuai dengan pernyataan dari Dollard dkk (dalam Heaven, 2001), hubungan antara prasangka dan trait kepribadian bukan hal yang baru dalam psikologi sosial. Ekehammar dan Akrami (2007), 
menyebutkan bahwa trait yang berkorelasi secara negatif dan sangat kuat dalam berprasangka sosial adalah openness dan Agreeableness. Extraversion 
juga menunjukkan korelasi yang negatif dengan prasangka sosial. Hal ini berarti semakin Openness, Agreeableness, Extraverted seseorang maka semakin kecil prasangka yang ditunjukan.

Berbeda dengan penelitian yang dilakukan oleh Ekehammar dan Akrami (2007), pada penelitian ini didapati bahwa trait yang berpengaruh secara signifikan terhadap prasangka sosial adalah trait Extraversion $(0,037)$ dan Conscientiousness $(0,030)$. Perbedaan hasil penelitian ini dengan penelitian sebelumnya dikarenakan pada penelitian Ekehammar dan Akrami (2009) menggunakan sampel dari latar belakang pendidikan yang cukup tinggi atau golongan akademis dan dari beberapa siswa sekolah menengah atas.

Melalui uji analisis regresi hasil penelitian ini menunjukkan bahwa variabel religiusitas dan trait kepribadian big five secara keseluruhan memberikan sumbangan kontibusi sebesar $41,9 \%$ dari bervariasinya prasangka sosial dan signifikan. Sedangkan $58,1 \%$ lainnya dipengaruhi oleh faktor lain selain variabel religiusitas dan trait kepribadian big five yang tidak terukur dalam penelitian ini yang dapat memberikan perubahan terhadap prasangka sosial kepada jama'ah tabligh. Penelitian yang dilakukan oleh Rowatt, et al. (2009), ada korelasi yang relatif kecil dan negatif antara general religiousness dan self reported racial prejudice, ketika dikontrol oleh perbedaan individu (umur, pendapatan, pendidikan, gender. dan ras)

Berdasarkan dari banyak literatur yang peneliti temui bahwa tipe kepribadian yang sangat erat hubungannya adalah tipe kepribadian RWA, disamping itu agar mendapatkan hasil yang kemungkinan berbeda jika menggunakan kepribadian Big Five. Selain itu jika menggunakan trait kepribadian Big Five agar mengikutsertakan Facets dari Big Five agar hasil penelitian menjadi lebih kaya. Seperti diketahui $58,9 \%$ bervariasinya prasangka sosial masih belum terukur dalam penelitian ini. Peneliti juga mendapatkan keterangan dari beberapa literatur bahwa variabel demografis seperti pendapatan, latar belakang pendidikan, dan yang lainnya bisa mempengaruhi prasangka sosial.

Perbanyak informasi mengenai jama'ah tabligh dan kegiatan-kegiatan yang dilakukan dan adakan forum diskusi antara jama'ah tabligh dengan masyarakat untuk memperoleh informasi lebih banyak tentang jama'ah tabligh saling mendukung dalam kegiatan yang berkaitan dengan keagamaan. 


\section{DAFTAR PUSTAKA}

Aboud, Frances E. (2005). Chapter Nineteen: The Development of Prejudice in Childhood and Adolescense. Dalam John F. Dovidio, Peter Glick, \& Laurie A. Rudman (Ed). On the Nature of Prejudice: Fifty Years after Allport (hal 310- 324). Gospons: Blackwell Publishing.

American Psychological Association Council of Representatives (2007, Agustus 16). Resolution on Religious, Religion-Based and/or Religio Derived Prejudice.

Ancok, J. \& Suroso, Fuad N. (2004). Psikologi Islami. Yogyakarta: Pustaka pelajar.

Augostinos, Martha., \& Reynolds, Katherine J. (2001). Chapter One: Prejudice, Racism, and Social Psychology. Daiam Martha A. \& Katherine J.R (Ed). Understanding Prejudice, Racism, and Social Conflict (hal 1-23). London: Sage Publishing.

Baron, Robert A. \& Byrne, D. (2003). Psikologi Sosial: Jilid 1 Edisi Kesepuluh. Jakarta: Erlangga.

Batson, C. Daniel. \& Stocks, E.L (2005). Chapter Twenty-Five: Religion and Prejudice. Dalam John F. Dovidio, Peter Glick, \& Laurie A. Rudman (Ed). On the Nature of Prejudice: Fifry Years after Alport (hal. 413-425). Gospons: Blackwell Publishing.

Blair, Irene V. (2002) Personality and Social Psychology Review: The Malleability of Automatic Stereotypes and Prejudice. Colorado: Lawrence Erlbaum Associate, Inc.

Brown, Rupert. (2010). Prejudice: Ils Social Psychology Second Edition. USA: Wiley-Blackwell.

Burhani R (Ed). (2009). Pemeriksaan Jamaah Tabligh di Jateng Hal Biasa. Diambil tanggal 14 Maret 2011, dari http://www.antaranews.com

Chaplin, James P. (2008). Kamus lengkap Psikologi. Jakarta: PT. Raja Grafindo Persada.

Dister, Niko Syukur. (1982). Pengalaman dan Motivasi Beragama. Jakarta: LEPPENAS.

Duckitt, John (2005). Chapter Twenty-Four: Personality and Prejudice. Dalam John F. Dovidio, Peter Glick, \& Laurie A. Rudman (Ed). On the Nature of Prejudice: Fifty Years after Allport (hal. 395- 410). Gospons: Blackwell Publishing.

Ekehammar, Bo. \& Akrami, N. (2007). Journal of Personality: Personality and Prejudice: From Big Five Personality Factors to Facets. Uppsala: Blackwell Publishing, Inc.

Engler, Barbara. (2009). Personality Theories: An Introduction Eight Edition. Boston: Houghton Mifflin Hartcourt Publishing. 
Feist, J \& Feist, G.J. (2010). Teori Kepribadian: Buku 1 Edisi 7. Jakarta: Salemba Humanika. 
Fetzer Institute and National Institute on Aging working Group. (1999). Multidimensional measurement of religiousness, spirituality for use in health research. Fetzer Institute in collaboration with the National Institute on Aging. Kalamazoo.

Fishbein, Harold D. (2002). Peer Prejudice and Discrimination: The Origins of Prejudice Second Edition. New Jersey: Lawrence Erlbaum Associates, Inc.

Friedman, Howard S. \& Schustack, M.W. (2008). Kepribadian: Teori Klasik dan Riset Modern. Jakarta: Erlangga.

Gaza (2007, Maret 13). Analisa terhadap Fitnah yang Melanda Jama'ah Tabligh di Search Engine Google [posting entril. Diambil tanggal 08 Juli 2013, dari http://myquran.org

Heaven, Patrick C.L. (2001). Chapter Six: Prejudice and Personality: The Case of the Authoritarian and Social Domenator. Dalam Martha A. \& Katherine J.R (Ed). Understanding Prejudice, Racism, and Social Conflict (hal. 89-104). London: Sage Publishing.

Irmawati. (2004). Pengaruh Prasangka Sosial terhadap Perspesi Kemampuan Kerja Karyawan. Skripsi, Fakultas Ilmu Sosial dan Ilmu Politik Universitas Sumatera Utara.

Joreskog, K.G. dan Sorbom, D. (2004). Lisrel 8.70. USA: Scientific Software International. Inc.

Mavor, Kenneth L, Laythe. B. \& Louis, w R. (2011) Journal for the Scientific Study of Religion: Religion, Prejudice, and Authoritarianism: Is RINA a Boon or Bane to the Psychology of Religion?. Canberra: The Society for the Scientific Study of Religion.

Pervin, Lawrance A., Cervone, Daniel. \& John, Oliver P. (2005). Personality: Theory and research. USA: John Wiley \& Sons, Inc.

Plous, S. (2003). The Psychology of Prejudice, Stereotyping, and Discrimination: An overview. In S. Plous (Ed.), Understanding Prejudice and Discrimination (pp. 3-48). New York: McGraw-Hill. Diambil pada Juni 2010, dari http://www.understandingprejudice.org/apa/english/

Putra, Idamsyah E., \& Pitaloka, Ardiningtyas. (2012). Psikologi Prasangka: Sebab, Dampak, dan Solusi. Bogor: Ghalia Indonesia.

Radloff, T.D. \& Evans, Nancy J. (2003). NASPA Journal, Vol. 40, No. 2: The Social Construction of Prejudice among Black and White College Students. Iowa.

R, Adiyo. (2010). Faktor-Faktor Psikologis yang Memengaruhi Prestasi Belajar Statistika 1 \& 2. Skripsi, Fakultas Psikologi, Universitas Islam Negeri Syarif Hidayatullah Jakarta.

Rowatt, Wade C., (et al). (2009). Psychology of Religion and Spirituality: Association Among Religiousness, Social Attitudes, and Prejudice in a 
National Random Sample of American Adults. USA: American Psychological Association. 
Rusydi, A. (2012). Religiusitas dan Kesehatan Mental (studi pada Aktivis Jama'ah Tabligh Jakarta Selatan). Tangerang Selatan: YPM

Sarwono, S.W. (2006). Psikologi Prasangka orang Indonesia. Jakarta: PT. RajaGrafindo Persada.

Zhao, Hao., \& Seibert, Scott E. (2006). The Big Five Personality Dimension and Entrepreneurial Status: A Meta-Analytical Review. USA: American

Psychological 